\section{The Developmental Changes and Correlation of Adiponectin, Adiponectin Receptors and Hormones of the Hypothalamic-Pituitary-Ovarian Axis in Growing Wannan Spotted Gilts}

\section{Abstract}

Adiponectin(Adp) is an adipocyte-derived hormone that plays an important role in lipid metabolism and glucose homeostasis, and could preserve reproductive functions by stimulating hypothalamic-pituitary-gonadal axis activities at different levels. To investigate and verify the relationship between the Adp and the hypothalamic-pituitary-ovarian axis (HPO axis) in Wannan spotted gilts, serum reproductive hormones, serum Adp and mRNA expression of Adp, AdpR1, AdpR2, GnRH, GnIH, GnRHR, LH, FSH, FSHR, and CYP19 in HPO axis of 1, 30, 45, 90, and 180-day-old Wannan spotted gilts were measured with ELISA and quantitative RTPCR using $\beta$-actin as an internal standard, respectively. The developmental pattern of serum FSH, and LH levels reaching the peak at $30 \mathrm{~d}$, followed by a significant decline on $45 \mathrm{~d}$. Serum Adp showed an opposite developmental pattern. The mRNA levels showed a similar relationship between serum hormones and Adp in Wannan spotted gilts. Thus we postulated that Adp may inhibit the secretion of some hormones in HPO axis through endocrine pathways and its action is mediated by AdpR during the prepubertal stages in Wannan spotted gilts.

Keywords: Wannan spotted gilt; Adiponectin(Adp); Adiponectin Receptors (AdpRs); reproductive hormone; HPO axis
Yun Li, Jie Zhou, Linqi Zhang, Kang Shao, Fugui Fang and Juhua Wang

College of Animal Science and Technology, Anhui Agricultural University, Hefei 230036, P. R. China

\section{Corresponding author: Jie Zhou}

\section{$\equiv$ zhoujie@ahau.edu.cn}

College of Animal Science and Technology, Anhui Agricultural University, Hefei 230036, P. R. China

Tel: 0086-551-65786328

Fax: 0086-551-65785027

Citation: Li Y, Zhou J, Zhang L, et al. The Developmental Changes and Correlation of Adiponectin, Adiponectin Receptors and Hormones of the Hypothalamic-PituitaryOvarian Axis in Growing Wannan Spotted Gilts. J Biomedical Sci. 2016, 5:2.

Received: January 10, 2016; Accepted: February 25, 2016; Published: February 29, 2016

\section{Introduction}

Adipokines, secreted by adipose tissue, participate in the regulation of thermogenesis, feeding, and reproduction [1]. As an adipokine, adiponectin (Adp), also known as AdipoQ [2], Acrp30 [3], apM-1 [4], and GBP28 [5], is a homotrimer of three, $30 \mathrm{kDa}$ subunits [6], and is widely expressed in adipose tissue, heart, muscle, and placenta [7-10]. Adp circulates as a multimer in plasma, at concentrations from 8 to $25 \mu \mathrm{g} / \mathrm{ml}$ in humans, and exhibits sexual dimorphism, with higher levels observed in females [11]. It has been shown that serum Adp levels are lower in obesity. However, there is little information regarding the effects of adiponectin on reproduction. Accumulating evidence indicates that Adp plays an important role in the regulation of food intake [12] and energy homeostasis [4], as well as in reproduction [1317]. The biological role of Adp is mediated by three Adp receptors
(AdpRs): Adp receptor 1 (AdpR1), Adp receptor 2 (AdpR2), and T-Cad [18]. Expression of AdpR1 and AdpR2 is widespread, and had been identified not only in muscle, liver, and adipocytes, but also in the hypothalamus, pituitary, and ovary of humans and rodents [14,19-21].

The hypothalamic-pituitary-ovarian axis (HPO axis) is central to the female mammalian reproductive system. The hypothalamus releases gonadotropin-releasing hormone $(\mathrm{GnRH})$ in pulses and these stimulate the pituitary to secrete both luteinizing hormone ( $\mathrm{LH}$ ) and follicle-stimulating hormone (FSH), via the interaction between $\mathrm{GnRH}$ and the gonadotropin-releasing hormone receptor (GnRHR). FSH then acts on the folliclestimulating hormone receptor (FSHR) to stimulate the ovary to secrete estradiol (E2). The enzyme aromatase P-450, encoded by the CYP19 gene, is responsible for a key step in estrogen 
biosynthesis. Recent findings indicate that $\mathrm{GnRH}$ is not the sole hypothalamic regulatory neuropeptide of vertebrate reproduction, and gonadotropin-inhibitory hormone $(\mathrm{GnIH})$ also plays a key role in the suppression of reproduction [22-24]. There is limited information regarding the modulatory effect of Adp on reproductive functions at different levels of the gonadal axis in pigs, and most studies have focused on the effects of Adp on the ovary [25-27]. The effects of Adp on overall endocrine function of the HPO axis in pigs remains unclear.

Wannan Spotted pig is the local breed in Huangshan, China, and has the characteristics of early maturity, a high reproduction rate, disease resistance and high-quality pork. In order to understand the interrelationship between Adp and the HPO axis in Wannan Spotted gilts, we measured serum levels of reproductive related hormones and mRNA expression of these genes. To the best of our knowledge, this study is the first to identify the effects of Adp on developmental changes in the HPO axis of gilts and to demonstrate developmental patterns of $\mathrm{GnIH}$ expression in pigs. The aim of this study was therefore to investigate the modulatory action of Adp on reproductive functions at different levels of the $\mathrm{HPO}$ and to examine the role of Adp in endocrine regulation in gilts. This information will be of great significance for the further development and utilization of this breed.

\section{Materials and Methods}

\section{Animals}

All animal experiments were approved by the local Animal Care Committee. Twenty-five healthy, Wannan Spotted gilts were supplied by the Animal Husbandry and Veterinary Medicine Bureau of Yi County, Huangshan, China. Five gilts were humanely slaughtered for blood and tissue sampling at each of 1, 30, 45, 90 and 180 days of age. Blood was collected into serum separator tubes (BD Microtainer 365967) and centrifuged at $6000 \mathrm{~g}$ for 90 $\mathrm{s}$; resultant serum supernatant was stored at $-80^{\circ} \mathrm{C}$ until hormone assays were conducted. Hypothalamus, pituitary, and ovary were snap frozen in liquid nitrogen and maintained at $-80^{\circ} \mathrm{C}$ until required.

\section{Measurement of serum hormones}

Serum was assayed for the presence of Adp, GnRH, GnIH, FSH, $L H$, and E2 using pig ELISA kits (R\&D, USA). The sensitivity of the ELISA assays for Adp, GnRH, GnIH, FSH, LH, and E2 was given as $25 \mathrm{pg} / \mathrm{mL}, 1.0 \mathrm{mlU} / \mathrm{ml}, 1.0 \mathrm{pg} / \mathrm{mL}, 0.1 \mathrm{mlU} / \mathrm{ml}, 0.1 \mathrm{mlU} / \mathrm{ml}$, and $1.0 \mathrm{pg} / \mathrm{mL}$, respectively.

\section{Quantitative RT-PCR (qRT-PCR) of tissue samples}

Total RNA was extracted from tissues using Trizol Reagent (Takara, China) following the manufacturer's directions. RNA (1 mg) was converted into cDNA using QIAGEN Quantitect kit and qRT-PCR performed in triplicate using cDNA from 100 ng RNA as the starting material for all reactions. PCR reactions $(25 \mu \mathrm{l})$ were performed using SYBR ${ }^{\circledR}$ Premix Ex TaqTM II (Takara, China). All qRT-PCR reactions were measured using the Rotor-Gene 6000 Quantitative Real-time PCR instrument (Corbett, Australia), using thermal cycling conditions recommended by the manufacturer ( 40 cycles of $10 \mathrm{~s}$ at $95^{\circ} \mathrm{C}, 20 \mathrm{~s}$ at $60^{\circ} \mathrm{C}$, and $15 \mathrm{~s}$ at $72^{\circ} \mathrm{C}$ ). qRTPCR was performed using intron-spanning primers and all primers were designed using Primer 5.0 software and PrimerBLAST-NCBI. The 2- $\triangle \triangle C T$ (cycle threshold) method was used to calculate fold changes and $\beta$--actin was employed as an internal standard. Primer pairs (Shanghai Sangon, China) used for specific amplification of porcine Adp, AdpR1, AdpR2, GnRH, GnIH, GnRHR, LH, FSH, FSHR, CYP19, and $\beta$-Actin are listed in Table 1.

\section{Statistical analysis}

Each test was repeated in triplicate. Relative quantification of mRNA levels was performed according to the 2- $\triangle \Delta C T$ method [28]. All data were analyzed using SPSS 16.0 (SPSS Inc., Chicago, IL, USA). Results were expressed as Mean \pm SEM. Statistical analysis and evaluation were performed using one-way ANOVA and Bivariate correlation. A value of $\mathrm{P}<0.05$ was considered statistically significant.

\section{Results}

\section{Changes in Serum Adp, LH, FSH, and E2 secretion} during postnatal development

Mean serum Adp levels were lowest at 30 days of age, compared to all other days during postnatal development $(P<0.05)$ (Figure 1A). Similarly, E2 levels were lowest at day $30(P<0.01)$ (Figure 1B). In contrast, Serum FSH and LH levels exhibited a different pattern, showing an increase from day 1 to 30 and day 45 to 90 (Figures 1C and 1D). FSH, and LH levels were higher at day 30 than other days $(\mathrm{P}<0.01)$.

\section{Changes in AdpR1, AdpR2, GnRH, and GnIH mRNA}

\section{expression in the hypothalamus}

Adp mRNA levels were very low in the hypothalamus (Figure $\mathbf{2 E}$, data not shown). Expression of AdpR1 mRNA in hypothalamus increased between days 1 to 90 and then decreased by day 180

Table 1 Primer sequences and parameter used for real-time quantitative PCR.

\begin{tabular}{|c|c|c|c|}
\hline $\begin{array}{l}\text { Target } \\
\text { Genes }\end{array}$ & $\begin{array}{l}\text { GenBank } \\
\text { accession }\end{array}$ & Primer sequences $\left(5^{\prime}-3^{\prime}\right)$ & $\begin{array}{l}\text { Fragment } \\
\text { size(bp) }\end{array}$ \\
\hline B-Actin & U07786.1 & $\begin{array}{l}\text { F-CTCGATCATGAAGTGCGACGT } \\
\text { S-GTGATCTCCTTCTGCATCCTGTC }\end{array}$ & 114 \\
\hline$A d p$ & AY589691.1 & $\begin{array}{l}\text { F- CGAGAAGGGTGAGAAAGGAGAT } \\
\text { R- ATGCTGAACGGTAGACATAGGC }\end{array}$ & 155 \\
\hline$A d p R 1$ & AY578142.1 & $\begin{array}{l}\text { F- GAGCATCTTCCGCATCCAC } \\
\text { S- GAACATCCCAAACACCACCTT }\end{array}$ & 151 \\
\hline$A d p R 2$ & AY606803.1 & $\begin{array}{l}\text { F- GCCACCATAGGGCAGATTG } \\
\text { S- GCCAGCCACCACGAAGAT }\end{array}$ & 159 \\
\hline$G n R H$ & NM_214274.1 & $\begin{array}{l}\text { F- AGCGCTTTGAGTGCACCGCT } \\
\text { S- TGCTCGCTGTCAGTGTCTCTGGT }\end{array}$ & 133 \\
\hline GnIH & GnIH & $\begin{array}{l}\text { F- GAGAGCAGCCCTGGGGCAATAG } \\
\text { S-TGAACGCGTGGATTGTTGGAGCA }\end{array}$ & 165 \\
\hline GnRHR & NM_214273 & $\begin{array}{l}\text { F-AGCCAACCTGTTGGAGACTCTGAT } \\
\text { R-AGCTGAGGACTTTGCAGAGGAACT }\end{array}$ & 101 \\
\hline$L H-B$ & NM_214080 & $\begin{array}{c}\text { F-ATGCTCCAGAGACTGCTGTTGT } \\
\text { R-TGCTGGTGGTAAAGGTGATGCAGA }\end{array}$ & 151 \\
\hline FSH-B & NM_213875.1 & $\begin{array}{l}\text { F-TTGCTGCAATAGCTGTGAGCTC } \\
\text { R- TTTCTGGATGTTGGGCCTG }\end{array}$ & 154 \\
\hline$F S H-R$ & NM_214386 & $\begin{array}{l}\text { F- TCGAGGCAAATGTGTTCTCC } \\
\text { S- AAGGTTCTGGAAGGCATCAG }\end{array}$ & 101 \\
\hline CYP19 & SSU92246 & $\begin{array}{l}\text { F- CTCGAGTTTTTCCCCAAGC } \\
\text { S- ACTGGCCTTGCTGTGTTTG }\end{array}$ & 190 \\
\hline
\end{tabular}




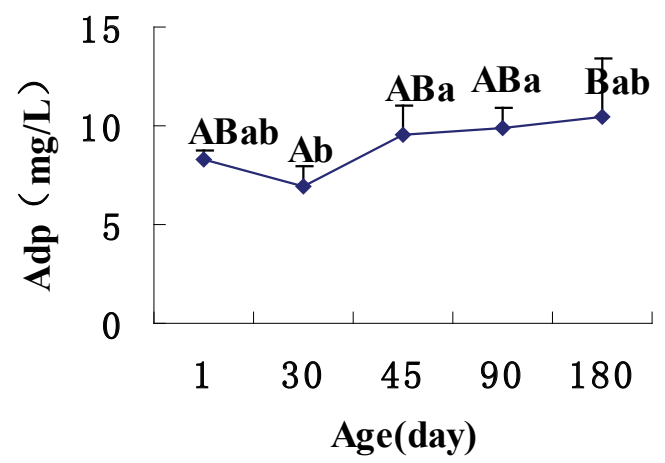

A

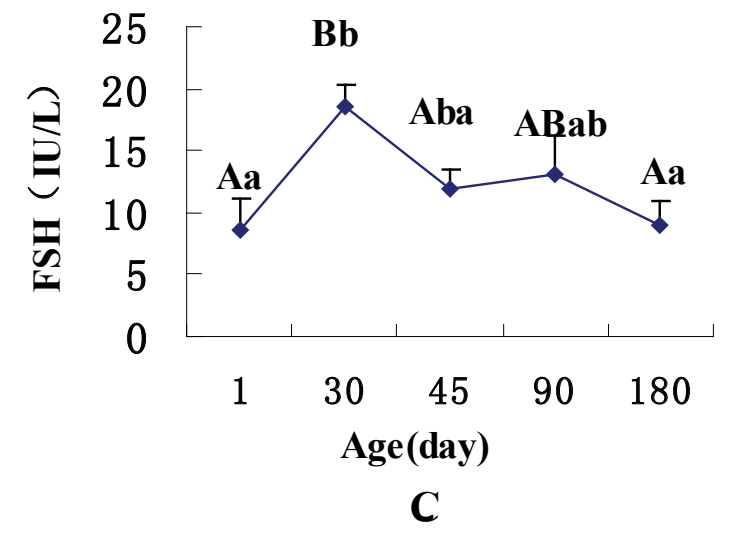

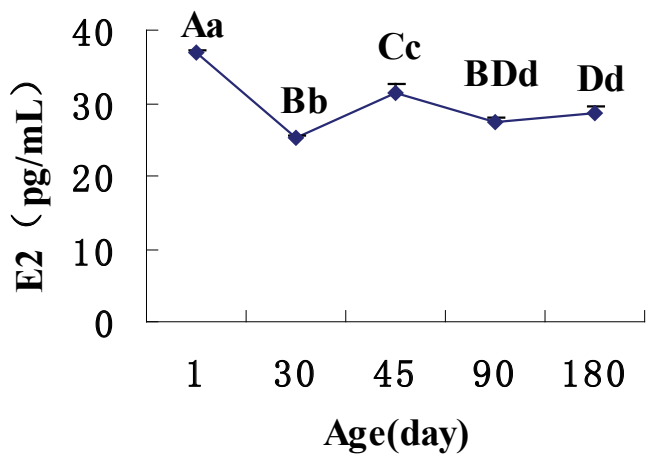

B

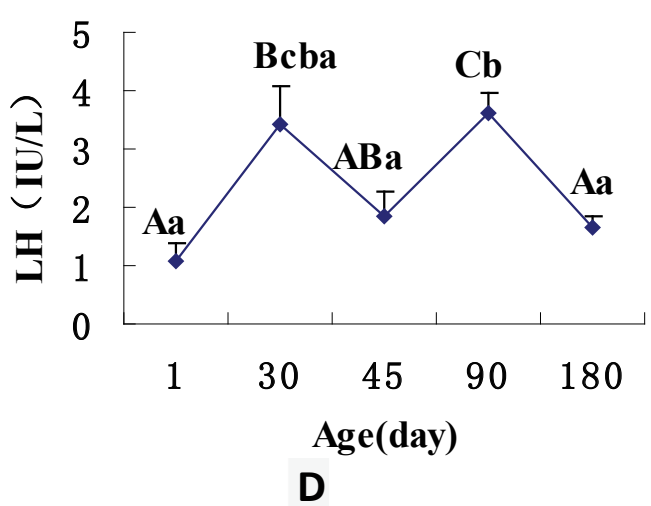

Figure 1 Developmental patterns of serum Adp (A), E2 (B), FSH (C) and LH (D) concentration in Wannan Hua sows by ELISA. The different small letters and capital letters stand for $\mathrm{P}<0.05$ or $\mathrm{P}<0.01$ between ages respectively. The same as follows. Data represent mean $\pm S E M, n=5$.

(Figure 2A). AdpR2 mRNA expression increased progressively during postnatal development (Figure 2B). GnRH mRNA expression was lowest at day 30 compared to all other time points measured $(P<0.05)$ (Figure $2 \mathrm{C}$ ). GnIH mRNA expression decreased between days 1 to 90 and then increased by day 180 (Figure 2D).

\section{Changes in AdpR1, AdpR2, FSH, LH and GnRH-R mRNA Expression in the pituitary gland}

Adp mRNA levels were also very low in the pituitary gland (Figure 3E). AdpR1 and AdpR2 mRNA expression decreased between days 1 to 30, increased at day 45 and then decreased again by day 180 (Figure 3A). In contrast, FSH, LH and GnRH-R mRNA expression increased between days 1 to 30, decreased at day 45 and then increased by day 90 (Figures 3B-3D). Correlation analyses showed a negative correlation between AdpR2 mRNA levels and GnRHR ( $r=-0.639, P<0.01)$, LH- $\beta(r=-0.507 ; P<0.05)$, and serum FSH levels ( $r=-0.460, P<0.05)$. AdpR1 mRNA levels correlated positively with AdpR2 mRNA levels $(r=0.517, P<0.05)$.

\section{Changes in AdpR1, AdpR2, CYP19, and FSH-R mRNA Expression in the ovary}

Ovarian AdpR1 mRNA expression increased significantly to reach a peak at 30 to 90 days $(P<0.05$; Figure 4A). The pattern of $A d p R 2$ mRNA expression was similar to that of AdpR1 $(P<0.01$; Figure 4B). CYP19 mRNA expression maintained consistently low levels from days 1 to 45, but was higher on day 90 (Figure 4C). FSH-R mRNA expression increased progressively from days 1 to 45 and then decreased to a nadir at day 90 (Figure 4D). Correlation analysis showed AdpR1 mRNA levels correlated positively with AdpR2 mRNA levels ( $r=0.380 ; P<0.05)$, and negatively with CYP19 mRNA $(r=-0.472 ; P<0.05)$ and serum E2 levels $(r=-0.416$; $\mathrm{P}<0.05)$.

\section{Discussion}

Adipose tissue play a crucial role in energy homeostasis, not only by storing triglycerides, but also in response to neural, nutrient, and hormonal signals mediated through adipokine (leptin, adiponectin, and resistin) secretion [1]. It is well known that leptin plays a role in the regulation of energy homeostasis and reproduction, and acts as a mediator in the crosstalk between adipose tissue and the HPO axis [1,29]. Recently, several studies have demonstrated that Adp also participates in the regulation of energy expenditure, thermogenesis, and food intake in the HPO axis $[12,14,30]$. 


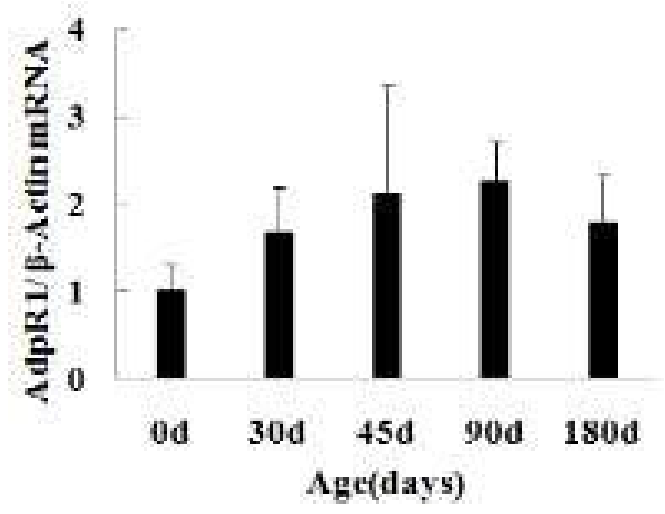

A

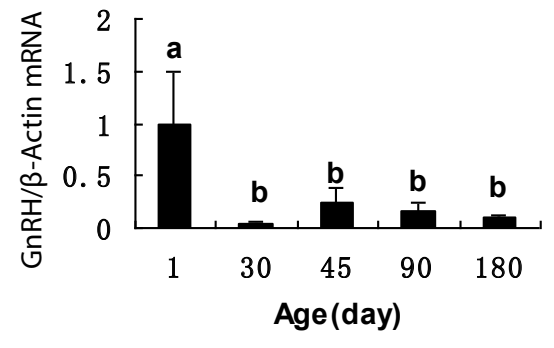

C
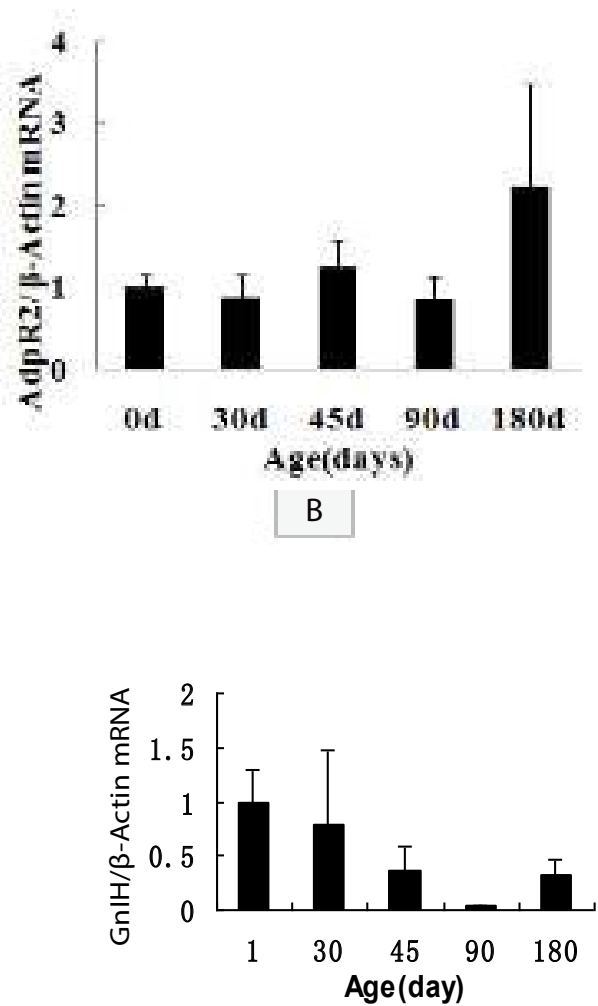

D

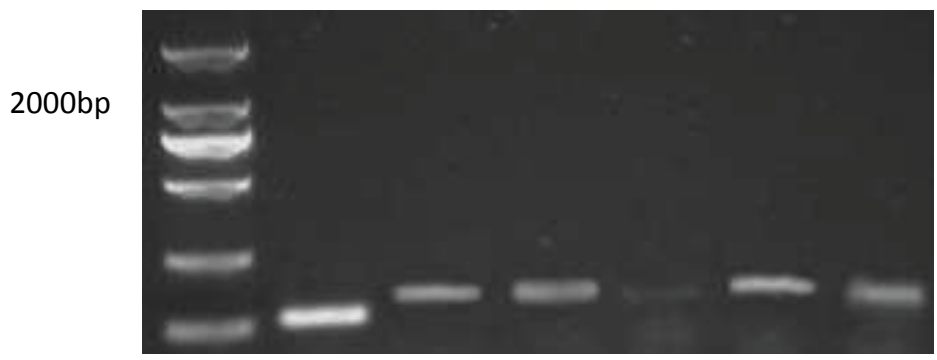

Marker B-Actin AdpR1 AdpR2 Adp GnRH GnIH

LD2000

E

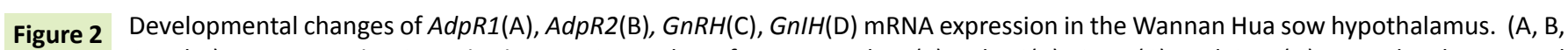

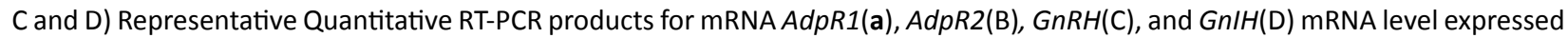
as arbitrary units relative to $\beta$-actin mRNA, respectively. (E) Representative agarose gel electrophoresis of RT-PCR production of cDNA. The different small letters and capital letters stand for $\mathrm{P}<0.05$ or $\mathrm{P}<0.01$ between ages respectively. The same as follows. Data represent mean $\pm S E M, n=5$.

Adp has been found in porcine follicular fluid at concentrations equivalent to that found in serum [25], although, Adp mRNA has not been previously identified in porcine ovarian or brain tissue [27]. In the present study, we found that porcine Adp mRNA was detected at very low levels in the hypothalamus, pituitary, and ovary. AdpRs mRNA is expressed widely in peripheral tissues, the brain, and granulosa cells in pigs $[25,31]$. In this study, we demonstrated that AdpRs mRNA is expressed in the HPO axis and shows no significant changes during postnatal development. We also found that serum Adp concentrations ranged between
5 to $15 \mathrm{mg} / \mathrm{L}$ over the study period. Based on these results, we speculate that Adp produced in adipose tissue plays a role as an endocrine modulator in the reproductive function of the HPO, mediated through AdpR. Although we did not investigate how Adp reaches the brain, a previous study has shown that Adp does not cross the blood-brain barrier [19]. Thus, the mechanism through which Adp regulates the reproductive functions of the HPO axis requires further investigation.

The hormones of the HPO axis play an important role in HPO 


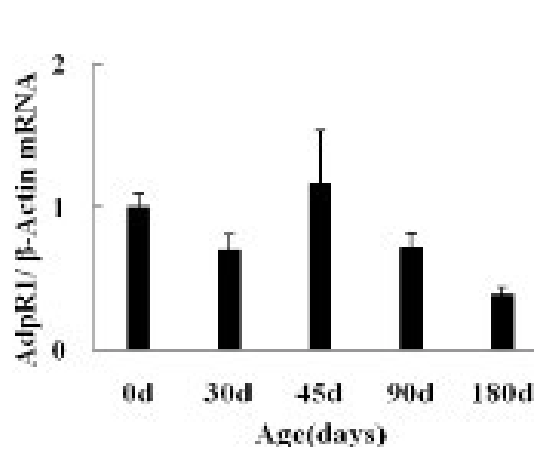

A

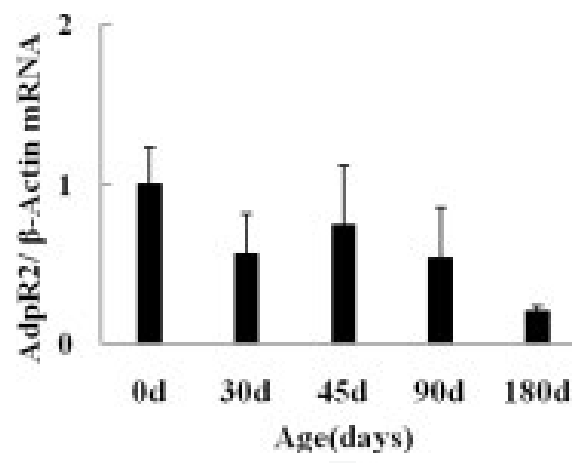

B

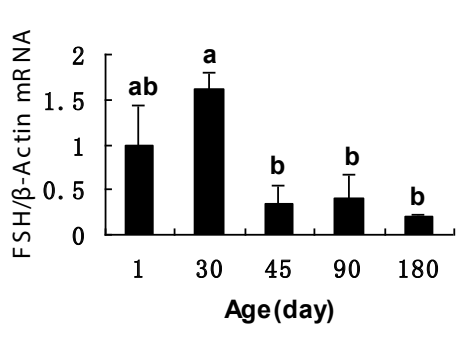

C

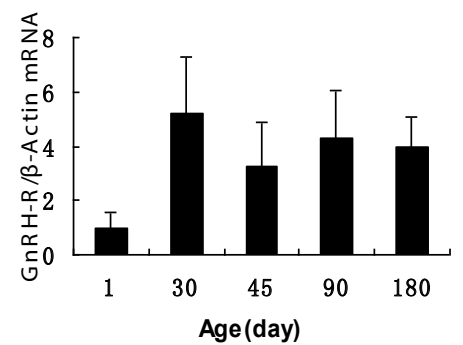

D

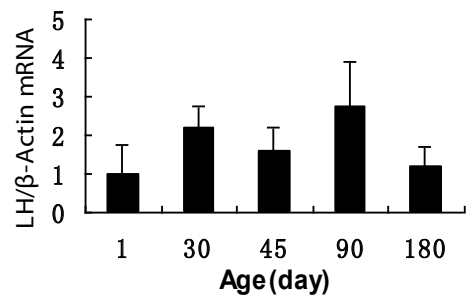

E

2000bp

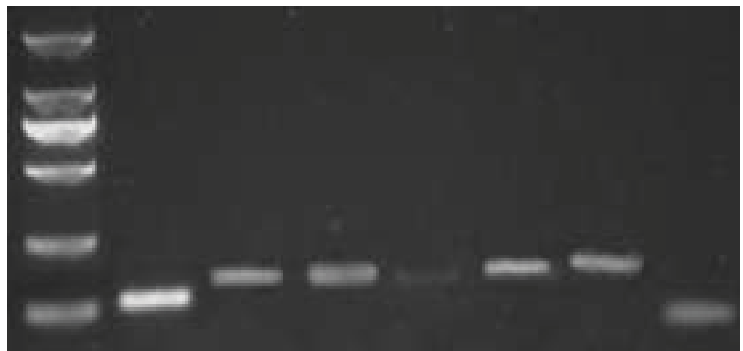

Marker $\beta$-Actin AdpR1 AdpR2 Adp LH- $\beta$ FSH- $\beta$ GnRH-R

LD2000

\section{F}

Figure 3 Developmental changes of $A d p R 1, A d p R 2, F S H, L H, G n R H-R$ and $A d p$ mRNA expression in the Wannan Hua sow pituitary. (A, B, C, $\mathrm{D}, \mathrm{E}$ and F) Representative Quantitative RT-PCR products for mRNA AdpR1(a), AdpR2(B), FSH (C), GnRH-R (D), and LH (E) mRNA level expressed as arbitrary units relative to $\beta$-actin mRNA, respectively. (F) Representative agarose gel electrophoresis of RT-PCR production of cDNA. The different small letters and capital letters stand for $\mathrm{P}<0.05$ or $\mathrm{P}<0.01$ between ages respectively. The same as follows. Data represent mean $\pm S E M, n=5$.

axis development. Serum Adp levels have been shown to be inversely correlated with androgen levels in humans [32-34] and Adp inhibits both basal and GnRH-stimulated $\mathrm{LH}$ secretion in short-term treated rat pituitary cells [14]. At the level of the rat hypothalamus, Adp also influences oxytocin-secreting neuron excitability, perhaps explaining the increased oxytocin secretion observed in the obese human population [35]. Lu et al. demonstrated that Adp activated adenosine monophosphate protein kinase and decreased $\mathrm{LH}$ secretion in mouse L $\beta T 2$ immortalized gonadotropic cells [13]. Furthermore, AdpRs mediate adiponectin to increase production of progesterone and E2 by insulin-like growth factor (IGF) in humans [36]. Adp has also been shown to inhibit progesterone and LH-dependent insulin production by bovine theca cells in vitro $[37,38]$. These studies suggest Adp does have an effect on reproduction. Here, we observed that the pattern of serum $\mathrm{FSH}$, and $\mathrm{LH}$ reaching the peak at 30d, followed by a significant decline on $45 \mathrm{~d}$. Serum Adp showed the opposite developmental pattern. These results imply that Adp may be involved in regulation of the early development of the reproductive axis in swine. The down regulation of serum Adp on day 30 may be due to increased levels of reproductive hormones. The longitudinal pattern of hypothalamic and 

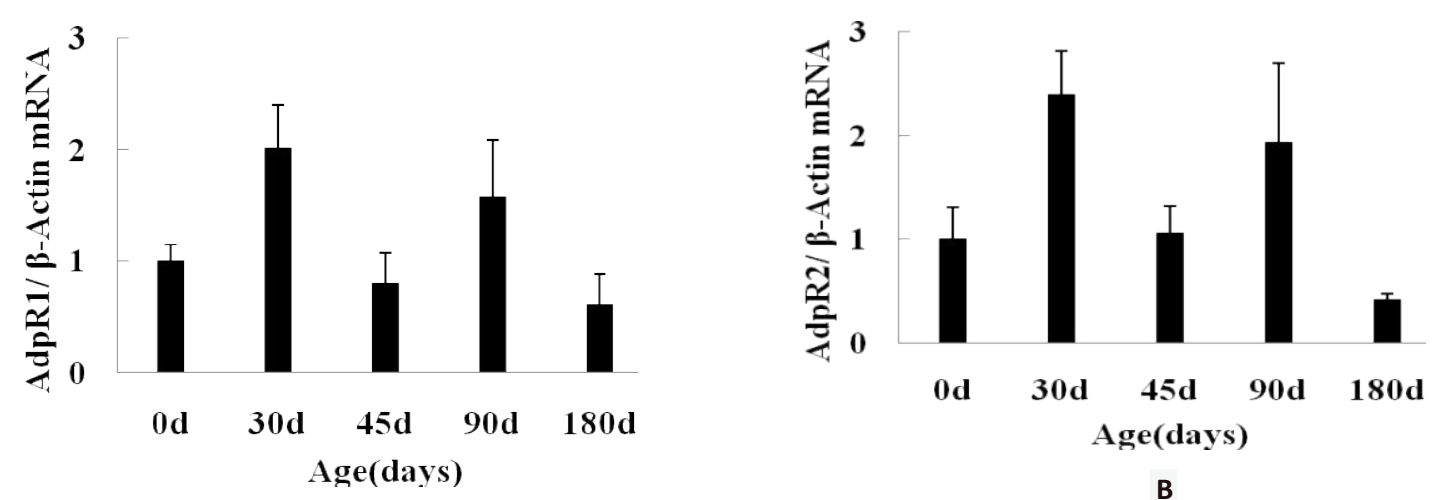

A

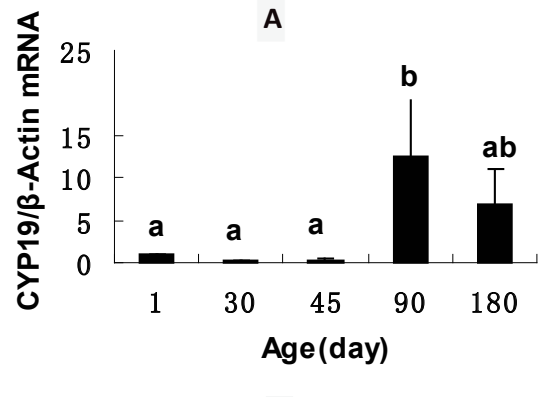

B

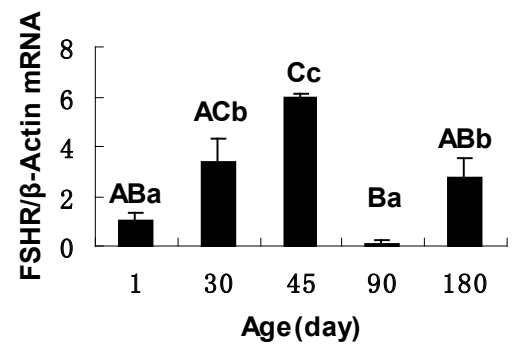

D

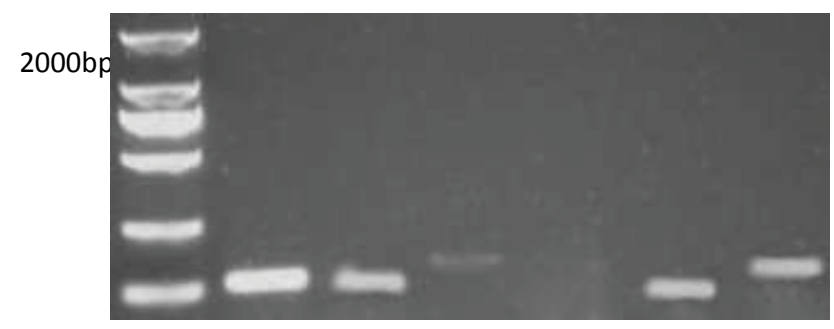

Marker $\beta$-Actin AdpR1AdpR2 Adp FSH-R CYP19

LD2000

Figure 4 Developmental changes of $A d p, A d p R 1, A d p R 2, C Y P 19$ and FSH-R mRNA expression in the Wannan Hua sow ovarian. (e) Representative agarose gel electrophoresis of RT-PCR production of cDNA. (A, B, C, and D) Representative Quantitative RT-PCR products for mRNA AdpR1(A), $\operatorname{AdpR2(B),CYP19~(C)~and~FSH-R(D)~mRNA~level~expressed~as~arbitrary~units~relative~to~} \beta$-actin mRNA, respectively. The different small letters and capital letters stand for $\mathrm{P}<0.05$ or $\mathrm{P}<0.01$ between ages respectively. The same as follows. Data represent mean $\pm S E M, n=5$.

pituitary mRNA expression showed a similar relationship to serum hormones and Adp. Furthermore, AdpR1 mRNA levels were inversely correlated with CYP19 mRNA and serum E2 in the ovary. These results suggest that Adp inhibited the secretion of hormones in the HPO axis in Wannan Spotted gilts.

\section{Conclusion}

In this study we have shown that serum reproductive hormones and Adp levels changed over time and showed reverse developmental changes during prepuberty in Wannan Spotted gilts. We propose that Adp may inhibit the hormones of the HPO axis through endocrine pathways and this action is mediated by AdpR during the prepubertal stages of development. These results benefit the further agricultural development and utilization of Wannan Spotted gilts.

\section{Acknowledgments}

This study was supported by the grants from National Natural Science Foundation of China (No. 30771581) and Natural Science Foundation of Anhui province (No. 1208085MC44). 


\section{References}

1 Ahima RS, Flier JS (2000) Adipose tissue as an endocrine organ. Trends Endocrinol Metab 11: 327-332.

2 Hu E, Liang P, Spiegelman BM (1996) AdipoQ is a novel adiposespecific gene dysregulated in obesity. J Biol Chem 271: 10697-10703.

3 Scherer PE, Williams S, Fogliano M, Baldini G, Lodish HF (1995) A novel serum protein similar to $\mathrm{C} 1 \mathrm{q}$, produced exclusively in adipocytes. J Biol Chem 270: 26746-26749.

4 Maeda K, Okubo K, Shimomura I, Funahashi T, Matsuzawa Y, et al. (1996) cDNA cloning and expression of a novel adipose specific collagen-like factor, apM1 (AdiPose Most abundant Gene transcript 1). Biochem Biophs Res Commun 221: 286-289.

5 Nakano Y, Tobe T, Choi-Miura NH, Mazda T, Tomita M (1996) Isolation and characterization of GBP28, a novel gelatin-binding protein purified from human plasma. J Biochem 120: 803-812.

6 Trujillo ME, Scherer PE (2005) Adiponectin--journey from an adipocyte secretory protein to biomarker of the metabolic syndrome. J Intern Med 257: 167-175.

7 Yamauchi T, Kamon J, Waki H, Terauchi Y, Kubota N, et al. (2001) The fat-derived hormone adiponectin reverses insulin resistance associated with both lipoatrophy and obesity. Nat Med 7: 941-946.

8 Maddineni S, Metzger S, Ocon O, Hendricks G, Ramachandran R (2005) Adiponectin gene is expressed in multiple tissues in the chicken: Food deprivation influences adiponectin messenger ribonucleic acid expression. Endocrinology 146: 4250-4256.

9 Piñeiro R, Iglesias MJ, Gallego R, Raghay K, Eiras S, et al. (2005) Adiponectin is synthesized and secreted by human and murine cardiomyocytes. FEBS Lett 579: 5163-5169.

10 Chen J, Tan B, Karteris E, Zervou S, Digby J, et al. (2006) Secretion of adiponectin by human placenta: differential modulation of adiponectin and its receptors by cytokines. Diabetologia 49: 12921302.

11 Nishizawa $\mathrm{H}$, Shimomura $\mathrm{H}$, Kishida K, Maeda N, Kuriyama $\mathrm{H}$, et al.(2002) Androgens decrease plasma adiponectin, an insulinsensitizing adipocyte-derived protein. Diabetes 51: 2734-2741.

12 Kubota N, Yano W, Kubota T, Yamauchi T, Itoh S, et al. (2007) Adiponectin stimulates AMP-activated protein kinase in the hypothalamus and increases food intake. Cell Metab 6: 55-68.

13 Lu M, Tang Q, Olefsky JM, Mellon PL, Webster NJ (2008) Adiponectin activates adenosine monophosphate-activated protein kinase and decreases luteinizing hormone secretion in L beta T2 gonadotropes. Mol Endocrinol 22: 760-771.

14 Rodriguez-Pacheco F, Martinez-Fuentes AJ, Tovar S, Pinilla L, TenaSempere $M$, et al. (2007) Regulation of pituitary cell function by adiponectin. Endocrinology 148: 401-410.

15 Bjursell M, Ahnmark A, Bohlooly-Y M, William-Olsson L, Rhedin M, et al. (2007) Opposing effects of adiponectin receptors 1 and 2 on energy metabolism. Diabetes 56: 583-593.

16 Yamauchi T, Nio Y, Maki T, Kobayashi M, Takazawa T, et al. (2007) Targeted disruption of AdipoR1 and AdipoR2 causes abrogation of adiponectin binding and metabolic actions. Nat Med 13: 332-339.

17 Combs TP, Pajvani UB, Berg AH, Lin Y, Jelicks LA, et al. (2004) A transgenic mouse with a deletion in the collagenous domain of adiponectin displays elevated circulating adiponectin and improved insulin sensitivity. Endocrinology 145: 367-383.
18 Hug C, Wang J, Ahmad NS, Bogan JS, Tsao TS, et al. (2004) T-cadherin is a receptor for hexameric and high-molecular-weight forms of Acrp30/adiponectin. Proc Natl Acad Sci U S A 101: 10308-10313.

19 Psilopanagioti A, Papadaki H, Kranioti EF, Alexandrides TK, Varakis JN (2009) Expression of adiponectin and adiponectin receptors in human pituitary gland and brain. Neuroendocrinology 89: 38-47.

20 Cheng XB, Wen JP, Yang J, Yang Y, Ning G, et al. (2011) GnRH secretion is inhibited by adiponectin through activation of AMP-activated protein kinase and extracellular signal-regulated kinase. Endocrine 39: 6-12.

21 Yamauchi T, Kamon J, Ito Y, Tsuchida A, Yokomizo T, et al. (2003) Cloning of adiponectin receptors that mediate antidiabetic metabolic effects. Nature 423: 762-769.

22 Li X, Su J, Lei Z, Zhao Y, Jin M, et al. (2012) Gonadotropin-inhibitory hormone $(\mathrm{GnIH})$ and its receptor in the female pig: cDNA cloning, expression in tissues and expression pattern in the reproductive axis during the estrous cycle. Peptides 36: 176-185.

23 Osugi T, Ukena K, Bentley GE, O'Brien S, Moore IT, et al. (2004) Gonadotropin-inhibitory hormone in Gambel's white-crowned sparrow (Zonotrichia leucophrys gambelii): cDNA identification, transcript localization and functional effects in laboratory and field experiments. J Endocrinol 182: 33-42.

24 Ciccone NA, Dunn IC, Boswell T, Tsutsui K, Ubuka T, et al. (2004) Gonadotrophin inhibitory hormone depresses gonadotrophin alpha and follicle-stimulating hormone beta subunit expression in the pituitary of the domestic chicken. J Neuroendocrinol 16: 999-1006.

25 Ledoux S, Campos DB, Lopes FL, Dobias-Goff M, Palin MF, et al. (2006) Adiponectin induces periovulatory changes in ovarian follicular cells. Endocrinology 147: 5178-5186.

26 Dai MH, Xia T, Zhang GD, Chen XD, Gan L, et al. (2006) Cloning, expression and chromosome localization of porcine adiponectin and adiponectin receptors genes. Domest Anim Endocrinol 30: 117-125.

27 Lord E, Ledoux S, Murphy BD, Beaudry D, Palin MF (2005) Expression of adiponectin and its receptors in swine. J Anim Sci 83: 565-578.

28 Livak KJ, Schmittgen TD (2001) Analysis of relative gene expression data using real-time quantitative PCR and the 2(-Delta Delta $C(T)$ ) Method. Methods 25: 402-408.

29 Yang S, Cheng L, Ma X, Zhao L, Dong X, et al. (2010) Leptin effects on the hypothalamic-pituitary-gonadal axis by activating proopiomelanocortin neurons Correlation between regulatory effects and duration. Neural Regeneration Research 5: 715-719.

30 Qi Y, Takahashi N, Hileman SM, Patel HR, Berg AH, et al. (2004) Adiponectin acts in the brain to decrease body weight. Nat Med 10: 524-529.

31 Lord E, Ledoux S, Murphy BD, Beaudry D, Palin MF (2005) Expression of adiponectin and its receptors in swine. J Anim Sci 83: 565-578.

32 Böttner A, Kratzsch J, Müller G, Kapellen TM, Blüher S, et al. (2004) Gender differences of adiponectin levels develop during the progression of puberty and are related to serum androgen levels. J Clin Endocrinol Metab 89: 4053-4061.

33 Lanfranco F, Zitzmann M, Simoni M, Nieschlag E (2004) Serum adiponectin levels in hypogonadal males: influence of testosterone replacement therapy. Clin Endocrinol (Oxf) 60: 500-507.

34 Page ST, Herbst KL, Amory JK, Coviello AD, Anawalt BD, et al. (2005) Testosterone administration suppresses adiponectin levels in men. Journal of Androl 26: 85-92. 
35 Hoyda TD, Fry M, Ahima RS, Ferguson AV (2007) Adiponectin selectively inhibits oxytocin neurons of the paraventricular nucleus of the hypothalamus. J Physiol 585: 805-816.

36 Chabrolle C, Tosca L, Rame C, Lecomte P, Royere D, et al. (2009) Adiponectin increases insulin-like growth factor I-induced progesterone and estradiol secretion in human granulosa cells. Fertil Steril 92: 1988-1996.
37 Lagaly DV, Aad PY, Grado-Ahuir JA, Hulsey LB, Spicer LJ (2008) Role of adiponectin in regulating ovarian theca and granulosa cell function. Mol Cell Endocrinol 284: 38-45.

38 Wen JP, Lv WS, Yang J, Nie AF, Cheng XB, et al. (2008) Globular adiponectin inhibits $\mathrm{GnRH}$ secretion from GT1-7 hypothalamic GnRH neurons by induction of hyperpolarization of membrane potential. Biochem Biophys Res Commun 371: 756-761. 